\title{
Ant-aphid interactions in multispecies ant communities: Some ecological and ethological aspects
}

\author{
Tatiana A. NOVGORODOVA \\ Institute of Animal Systematics and Ecology, Siber. Br., Russian Academy of Sciences, Frunze str., 11, 630091 Novosibirsk, Russi a; \\ e-mail: tanovg@yandex.ru
}

Key words. Ants-aphids interaction, Formicinae, Myrmicinae, Coccinella septempunctata, multispecies communities, symbiosis, aphid diversity, behaviour, trophobionts, foragers

\begin{abstract}
Investigations of the interactions between aphids and ants in multispecies ant communities and an experimental investigation of some ethological aspects of ant-aphid interactions were carried out in mixed forests at Novosibirsk Academic Centre, from 1998-2002. The eight species of ants investigated were characterized by different levels of territorial organization and interaction with aphids, which were associated with different degrees of specialization of the worker ants. The most myrmecophilous species of aphids (24 out of 33 species identified) were associated with the red wood ants. By placing Coccinella septempunctata Linnaeus (Coleoptera: Coccinellidae) in aphid colonies it was shown that only ants with large protected territories attacked the adults and larvae of the predator. Other species of ants either protected aphids only from adult ladybirds or did not guard them at all. Moreover, only individuals of Formica s. str., which has specialized workers, did not switch to collecting protein food. However, aphids make up a considerable part of the prey of ants, in which non-myrmecophilous aphids predominate (about $60-100 \%$ of the aphid prey). Moreover, ants only killed unattended or damaged myrmecophilous aphids. Formica s. str., which has the highest level of social and territorial organization, provides aphids with the most services and is the dominant species forming symbiotic relationships with aphids in the communities studied.
\end{abstract}

\section{INTRODUCTION}

The trophobiotic ant-aphid relationship is a classic example of a mutualistic interaction with a number of different levels of mutual dependence (Nixon, 1951; Cherix, 1987; Hölldobler \& Wilson, 1990; Stadler \& Dixon, 1999; Offenberg, 2001; Stadler et al., 2003; Novgorodova, 2004). Aphids are divided into two main groups: myrmecophilous (tended by ants) and nonmyrmecophilous (unattended). As predators and aphid tenders, ants have a great influence on the aphid fauna. The myrmecophilous species of aphids excrete sugar rich honeydew and possess specific adaptations for interacting with ants (Nixon, 1951; Novgorodova, 2002). The key question is what is the role of the different members of multispecies ant communities in this process.

Comparative analysis of the size and extinction rates of aphid colonies has shown that aphid survival depends on the species of ant interacting with them (Addicott, 1978; Bristow, 1984). This may be due to the behavioural strategies of the different species of ants that tend the aphids and collect their honeydew. Earlier it was shown that various species of ants differ in their division of labour and tending of aphids (Reznikova \& Novgorodova, 1998a, b). The following levels of specialization in ant-aphid interactions were revealed: unspecialized foragers, partial division of labour among the foragers and the specialization of the foragers into working groups. The latter is typical of the dominant species with the highest level of social organization. This indicates that the effect of the various ant species on the fauna and aphid populations is likely to differ.
The aim of this work was to investigate the interactions of aphids with ants different levels of social and territorial organization in multi-species ant communities. The work presents data on the interaction between myrmecophilous aphids and ants, and preliminary results of an investigation of some ethological aspects of ant-aphid interactions.

\section{MATERIAL AND METHODS}

\section{Sites investigated}

Investigations were conducted at Novosibirsk Academic Centre $\left(54^{\circ} 57^{\prime} \mathrm{N}, 83^{\circ} 06^{\prime} \mathrm{E}\right.$, alt. $200 \mathrm{~m}$ a.s.1.; area of $10 \mathrm{~km}^{2}$; average temperatures in June, July and August were 17.9, 18.2 and $16.7^{\circ} \mathrm{C}$, and precipitation, $85.2,84.3$ and $119.4 \mathrm{~mm}$, respectively) in mixed pine and birch-aspen forests.

\section{Ants}

The eight species of ants studied are listed in Table 1. They differ in their territorial organization, which ranges from unprotected feeding areas to large protected territories with networks of foraging trails (Dobrzańska, 1966; Dlusskiy, 1967; Dmitrienko \& Petrenko, 1976; Hölldobler \& Wilson, 1990) and in their interactions with aphids from unspecialized foragers to groups of specialized foragers (Novgorodova \& Reznikova, 1996; Reznikova \& Novgorodova, 1998a, b; Novgorodova, 2002).

Visual observation of ants on aphid colonies was facilitated by marking individuals and groups of ants with paint. In total, 350 individuals of $F$. polyctena, $178-F$. aquilonia, $215-F$. pratensis; $197-$ C. saxatilis, 269 - L. niger, $237-L$. fuliginosus, $486-F$. cunicularia and $64-F$. fusca were marked. Time spent observing aphid colonies ranged from 15 to $115 \mathrm{~h}$. 
TABLE 1. The species of ants and aphids studied.

\begin{tabular}{|c|c|c|c|c|c|}
\hline \multirow{2}{*}{\multicolumn{2}{|c|}{ Ants / abbreviation }} & \multicolumn{2}{|c|}{ Species peculiarities } & \multirow{2}{*}{$\begin{array}{c}\text { Ant } \\
\text { nests }\end{array}$} & \multirow{2}{*}{\begin{tabular}{|c|} 
Myrmecophilous aphids \\
Number of aphid colonies
\end{tabular}} \\
\hline & & Territorial organization & Interaction with aphids & & \\
\hline $\begin{array}{l}\text { Formica polyctena } \\
\text { Förster }\end{array}$ & F_pol & \multirow{4}{*}{$\begin{array}{l}\text { Protected territories with } \\
\text { particular groups of ants } \\
\text { foraging only in particular } \\
\text { parts of the territory }\end{array}$} & \multirow{3}{*}{$\begin{array}{l}\text { Specialized } \\
\text { working groups }\end{array}$} & 3 & $\begin{array}{c}9 \text { - Aphis jacobaeae Schrank } \\
23 \text { - Symydobius oblongus Heyden } \\
14 \text { - Chaitophorus populeti Panzer }\end{array}$ \\
\hline $\begin{array}{l}\text { Formica aquilonia } \\
\text { Yarrow }\end{array}$ & F_aq & & & 3 & $\begin{array}{l}27 \text { - Chaitophorus populeti Panzer } \\
19 \text { - Symydobius oblongus Heyden }\end{array}$ \\
\hline $\begin{array}{l}\text { Formica pratensis } \\
\text { Retzius }\end{array}$ & F_pr & & & 4 & 21 - Chaitophorus populeti Panzer \\
\hline $\begin{array}{l}\text { Lasius fuliginosus } \\
\text { Latreille }\end{array}$ & L_ful & & \multirow{2}{*}{$\begin{array}{l}\text { Unspecialized } \\
\text { workers }\end{array}$} & 3 & $\begin{array}{l}24 \text { - Stomaphis quercus Linnaeus } \\
11 \text { - Cinara boerneri Hille Ris Lambers }\end{array}$ \\
\hline $\begin{array}{l}\text { Lasius niger } \\
\text { Linnaeus }\end{array}$ & L_nig & \multirow{2}{*}{$\begin{array}{l}\text { Partially protected } \\
\text { territory }\end{array}$} & & 3 & $\begin{array}{l}\text { 9-Aphis craccivora Koch } \\
11 \text {-Aphis pomi } \text { Degeer } \\
13 \text { - Chaitophorus populeti } \text { Panzer }\end{array}$ \\
\hline $\begin{array}{l}\text { Camponotus saxatilis } \\
\text { Ruzsky }\end{array}$ & C_sax & & $\begin{array}{c}\text { Partial division of } \\
\text { labour }\end{array}$ & 3 & $\begin{array}{l}14-\text { Symydobius oblongus Heyden } \\
22 \text { - Chaitophorus populet } \text { Panzer }\end{array}$ \\
\hline $\begin{array}{l}\text { Formica cunicularia } \\
\text { glauca } \text { Ruzsky }\end{array}$ & F_cun & \multirow[b]{2}{*}{ Unprotected territory } & \multirow{2}{*}{$\begin{array}{l}\text { Unspecialized } \\
\text { workers }\end{array}$} & 10 & $\begin{array}{l}13 \text { - Aphis craccivora Koch } \\
26 \text { - Chaitophorus populeti Panzer }\end{array}$ \\
\hline $\begin{array}{l}\text { Formica fusca } \\
\text { Linnaeus }\end{array}$ & F_fus & & & 5 & $\begin{array}{l}13 \text { - Aphis craccivora Koch } \\
3 \text { - Cinara boerneri Hille Ris Lambers } \\
16 \text { - Chaitophorus populeti Panzer }\end{array}$ \\
\hline
\end{tabular}

\section{Myrmecophilous aphids}

Censuses of ant nests and aphid colonies on different plants were conducted several times a season and myrmecophilous aphids recorded. A total of 1842 samples of aphids and ants of the subfamilies Formicinae and Myrmicinae were collected and fixed in $70 \%$ alcohol.

\section{Experimental investigation of ant-aphid interactions}

Colonies of Chaitophorus populeti Panzer (on Populus tremula Linnaeus), consisting of 20-30 individuals, were used for the experiments (Table 1). The colonies consisted of 5-7 adults, 4-6 fourth instar nymphs, 6-8 third instar nymphs and 7-9 first or second instar nymphs. All experimental insects were collected locally on the day of the experiment. The ladybird, Coccinella septempunctata Linnaeus (Coleoptera: Coccinellidae), was kept in plastic boxes ventilated via holes covered with nylon netting. Aphids were collected by cutting stems infested with Ch. populeti and putting the cut ends of the stems into a glass of water. Each insect was used only once. Ant behaviour was recorded over a period $10 \mathrm{~min}$ after encountering the different experimental objects. Three nests of each species of ant were used in the following experiments.

\section{Experiment 1: Ants' reaction to potential predators}

Coccinella septempunctata (Coleoptera: Coccinellidae) was placed on plants near aphid colonies tended by each species of ant (25 adults and 25 larvae in each case; 1-2 adults and larvae of the predator were placed in each aphid colony at intervals of about $30 \mathrm{~min}$ ).

Experiment 2: Do ants recognize the aphids they tend?

Two types of "new" individuals of Ch. populeti were placed close to conspecific aphid colonies using a fine paint brush: "familiar" aphids, previously tended by the same colony of ants and "strangers", tended by other conspecific colonies (20 aphids were used in each test).

Experiment 3: Do ants switch from tending aphids to collecting protein food?

Crumbled boiled egg is a highly attractive source of protein food for ants. The ants' reaction to this kind of food placed close to their nest was the same in all cases: foragers transported it inside immediately. At the beginning of each experiment ants were removed from an aphid colony and the bait was placed on the plant close to the aphid colony. The behaviour of ants returning to the aphid colony was observed.

\section{Do ants hunt for aphids?}

Ant and aphid behaviour in aphid colonies was observed and the composition of ants' prey analysed. All prey was collected from ants near the entrance to their nests during the periods of their maximum activity. Time spent collecting prey was $10 \mathrm{~h}$ (one hour per day) for each of the ant species. Prey was collected over the period June 15 - July 15, 2000. One nest of each ant species was examined. The total number of prey items and the proportions made up of each group of insects were calculated.

The nests were located at four experimental sites. The number of myrmecophilous and non-myrmecophilous aphids at these sites was estimated by counting the number of aphids on branches selected at random on trees visited by ants and on grasses in $10 \mathrm{~m}^{2}$ areas.

\section{Data analysis}

The data were analyzed using STATISTICA (version 5.0). The ants' responses to potential predators, "new" aphids and protein food (choice tests: "to attack or not" and "to transport or not") were compared using $2 \times 2$ contingency tables (ChiSquare test, $\alpha=0.05$ ). Residence time of "strangers" on plants after the first contact with ants of various species were compared using the Wilcoxon-test.

\section{RESULTS}

\section{Myrmecophilous aphids}

Field studies showed that the richest complexes of myrmecophilous aphids (24 out of 33 species) were associated with the red wood ants Formica polyctena and $F$. aquilonia (Fig. 1), with 8 species of aphids only attended by them (Table 2 ). 


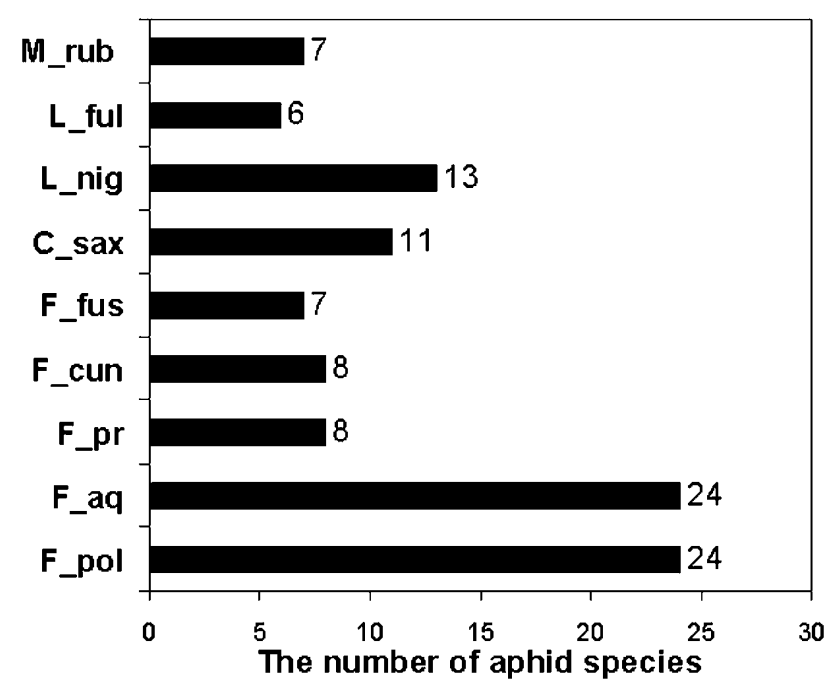

Fig. 1. The numbers of species of myrmecophilous aphids associated with the different ants. The abbreviations are defined in Table 1.

\section{Experimental investigations}

Experiment 1: Ants' reaction to potential predators of aphids

The reaction of the ants depended on the species (Table 3). F. cunicularia glauca and F. fusca did not protect aphid colonies from ladybirds, either adults or larvae. Other ants actively guarded aphids against ladybirds. However, C. saxatilis and L. niger protected aphids against the adults but not the larvae of ladybirds.

Experiment 2: Do ants recognize the aphids they tend?

Ants, which protected their territories and aphid colonies, distinguished familiar aphids from strangers (Table 3). Ants demonstrated the following behaviour: NeUTRAL - paid no attention to the aphids or palpated their bodies, ATTACK - pushed "strangers" off the plant or TRANSPORTED them to their nest. Reaction of all the ants studied was neutral ( $100 \%$ of cases) when they encountered "familiar" aphids (Table 3). However, all ants except $F$. cunicularia and $F$. fusca attacked "stranger" aphids almost immediately (in 2-45 s) (Fig 2), with Formica s. str. and $L$.

TABLE 2. Relationships of ants with aphids in mixed forests at Novosibirsk Academic Centre. The abbreviations are defined in Table 1

\begin{tabular}{|c|c|c|c|c|c|c|c|c|c|}
\hline Aphids / ants & F_pol & F_aq & F_pr & F_cun & F_fus & C_sax & L_ful & L_nig & M_rub \\
\hline \multicolumn{10}{|l|}{ Aphididae } \\
\hline Aphis brohmeri C.Börner & + & + & - & - & - & + & - & - & + \\
\hline A. craccivora Koch & + & + & + & + & + & - & - & + & - \\
\hline A. craccae Linnaeus & - & - & - & - & - & - & - & + & - \\
\hline A. evonymi Fabricius & + & + & - & - & - & - & - & - & - \\
\hline A. fabae Scopoli & + & + & - & - & - & + & - & - & + \\
\hline A. idaei Van der Goot & - & - & - & - & - & - & - & + & - \\
\hline A. jacobaeae Schrank & + & + & - & - & - & - & - & - & - \\
\hline A. pomi De Geer & + & + & - & + & - & - & - & + & - \\
\hline A. subnitidae C.Börner & + & + & - & - & - & - & - & - & - \\
\hline A. viburni Scopoli & - & + & - & - & - & - & - & + & - \\
\hline Chromaphis obiensis Ivanovskaja & - & - & - & - & - & - & - & + & - \\
\hline Macrosiphoniella pulvera Walker & + & - & - & + & - & - & - & - & - \\
\hline Rhopalosiphum padi Linnaeus & + & + & - & - & - & - & - & - & + \\
\hline Schizaphis gramina Rondani & + & + & - & - & - & - & - & - & - \\
\hline Sch.pyri Schaposhnikov & + & + & - & - & - & - & - & - & - \\
\hline \multicolumn{10}{|l|}{ Thelaxidae } \\
\hline Glyphina betulae Kaltenbach & + & + & - & - & - & + & - & - & - \\
\hline \multicolumn{10}{|l|}{ Lachnidae } \\
\hline Cinara boerneri Hille Ris Lambers & + & + & + & + & + & - & + & - & - \\
\hline C. laricis Walker & + & + & + & - & + & - & + & - & - \\
\hline C. piceae Panzer & + & + & - & - & - & - & - & - & - \\
\hline C. pinea Mordvilko & + & + & + & - & + & - & + & - & - \\
\hline C.pini Linnaeus & + & + & + & + & + & + & - & + & - \\
\hline C. pinihabitans Mordvilko & - & - & - & - & - & + & - & - & - \\
\hline Stomaphis quercus Linnaeus & - & - & - & - & - & - & + & - & - \\
\hline \multicolumn{10}{|l|}{ Drepanosiphidae } \\
\hline Calipterinella betularia Kaltenbach & + & + & - & - & - & - & - & + & + \\
\hline C. tuberculata Heyden & - & - & - & - & - & + & - & - & - \\
\hline Symydobius oblongus Heyden & + & + & + & - & - & + & + & + & - \\
\hline \multicolumn{10}{|l|}{ Chaitophoridae } \\
\hline Chaitophorus albus Mordvilko & + & + & - & + & - & + & - & + & + \\
\hline Ch. albitorosus Ivanovskaja & + & + & - & - & - & - & - & - & - \\
\hline Ch. nassonowi Mordvilko & - & - & + & - & - & - & - & - & - \\
\hline Ch. populeti Panzer & + & + & + & + & + & + & + & + & + \\
\hline Ch. populialbae Boyer de Fonscolombe & + & + & - & + & + & + & - & + & + \\
\hline Ch. salicti Schrank & + & + & - & - & - & - & - & - & - \\
\hline Ch. tremulae Koch & - & - & - & - & - & + & - & + & - \\
\hline
\end{tabular}


TABLE 3. Reactions of the various species of ants to different objects: data from the ethological experiments. Results within rows marked with $*$ and $* *$ differ significantly $(\mathrm{p}<0.001,2 \times 2$ contingency tables, Chi-Square test, $\mathrm{df}=1)$. The abbreviations are defined in Table 1.

\begin{tabular}{|c|c|c|c|c|c|c|c|c|c|}
\hline Object & Nest & F_pol & F_aq & F_pr & L_ful & L_nig & C_sax & F_cun & F_fus \\
\hline \multicolumn{10}{|c|}{ Experiment 1: Ants' reaction to potential predators (ladybird). (Attack/ neutral) } \\
\hline Adult & $1-3$ & $25 / 0^{*}$ & $25 / 0^{*}$ & $25 / 0^{*}$ & $25 / 0^{*}$ & $25 / 0^{*}$ & $25 / 0 *$ & $0 / 25 * *$ & $0 / 25 * *$ \\
\hline Larvae & $1-3$ & $25 / 0 *$ & $25 / 0 *$ & $25 / 0^{*}$ & $0 / 25^{* *}$ & $0 / 25 * *$ & $0 / 25 * *$ & $0 / 25 * *$ & $0 / 25 * *$ \\
\hline \multicolumn{10}{|c|}{ Experiment 2: Do ants recognize the aphids they tend? (Attack/ neutral) } \\
\hline \multirow{3}{*}{ “Stranger" } & 1 & $20 / 0^{*}$ & $20 / 0^{*}$ & $20 / 0^{*}$ & $20 / 0^{*}$ & $16 / 4^{*}$ & $15 / 5 *$ & $0 / 20 * *$ & $0 / 20 * *$ \\
\hline & 2 & $20 / 0^{*}$ & $20 / 0^{*}$ & $20 / 0^{*}$ & $20 / 0 *$ & $15 / 5 *$ & $16 / 4 *$ & $0 / 20 * *$ & $0 / 20 * *$ \\
\hline & 3 & $20 / 0^{*}$ & $20 / 0^{*}$ & $20 / 0^{*}$ & $20 / 0^{*}$ & $16 / 4^{*}$ & $15 / 5^{*}$ & $0 / 20 * *$ & $0 / 20 * *$ \\
\hline "Familiar" & $1-3$ & $0 / 20$ & $0 / 20$ & $0 / 20$ & $0 / 20$ & $0 / 20$ & $0 / 20$ & $0 / 20$ & $0 / 20$ \\
\hline \multicolumn{10}{|c|}{ Experiment 3: Do ants switch from tending aphids to collecting protein food? (Yes/no) } \\
\hline \multirow{3}{*}{ Protein food } & 1 & $0 / 30^{*}$ & $0 / 30^{*}$ & $0 / 42^{*}$ & $31 / 0^{* *}$ & $53 / 0^{* *}$ & $34 / 0^{* *}$ & $27 / 0 * *$ & $25 / 0^{* *}$ \\
\hline & 2 & $0 / 27 *$ & $0 / 33^{*}$ & $0 / 50^{*}$ & $39 / 0^{* *}$ & $27 / 0 * *$ & $44 / 0^{* *}$ & $23 / 0^{* *}$ & $27 / 0 * *$ \\
\hline & 3 & $0 / 44^{*}$ & $0 / 37^{*}$ & $0 / 36^{*}$ & $24 / 0^{* *}$ & $29 / 0 * *$ & $32 / 0 * *$ & $32 / 0^{* *}$ & $28 / 0^{* *}$ \\
\hline
\end{tabular}

fuliginosus showing the quickest response to "strangers" (Wilcoxon-test; $\mathrm{p}<0.05$ ). The percentage of aphids attacked was $100 \%$ for ants that protected their territories (F. polyctena, F. aquilonia, F. pratensis, L. fuliginosus) and slightly less for those that partially protected their territories (on average, $78.33 \pm 2.89 \%$ for $C$. saxatilis and $76.67 \pm 2.89 \%$ for $L$. niger; $\mathrm{n}_{1,2}=3$ ). Ants that do not protect their feeding areas ( $F$. cunicularia and $F$. fusca) responded similarly to "stranger" and "familiar" aphids. The reactions of the different ant species on encountering "stranger" aphids are presented in Fig. 3. Ants that protect their feeding territories actively guarded aphid colonies. However, ants that show a division of labour in the groups of workers that tend aphid colonies ( $F$. polyctena, $F$. aquilonia, $F$. pratensis) either threw dead aphids to the ground or put them on a leaf some distance from the aphid colony, but never transported them to their nest like the ants that don't have specialized workers (L. fuliginosus and L. niger). C. saxatilis, with a partial division of labour, occupies an intermediate position. Tending ants

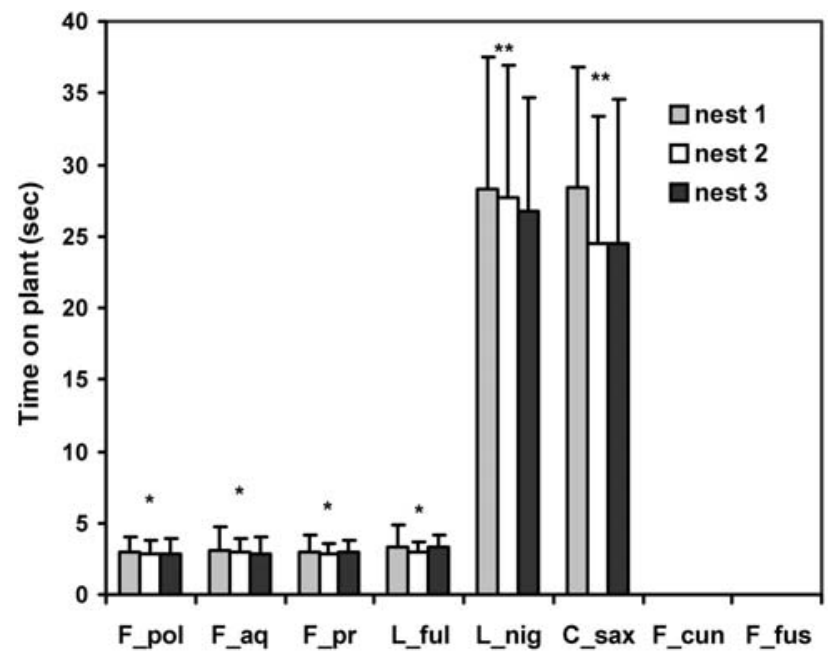

Fig. 2. Residence time of "stranger" aphids on plants after their first contact with an ant. The data marked with * and ** differ significantly (Wilcoxon-test, $\mathrm{p}<0.01$ ). The abbreviations are defined in Table 1. both transport dead aphids to their nest or left them for forager ants.

Experiment 3: Do ants switch from tending aphids to collecting protein food?

The decision "to switch or not" depends on the species of ants (Table 3). Reaction of conspecific ants was identical. There are two groups of ants. They either continued tending aphids after a short inspection (2-6 s) of the protein food (boiled egg) (F. polyctena, $F$. aquilonia and $F$. pratensis) or immediately transported the food back to their nest. The differences in behaviour of individuals of the first and second group are highly significant $(2 \times 2$ contingency tables, Chi-Square test, $\mathrm{df}=1, \mathrm{p}<0.001$ ).

\section{Do ants hunt for aphids?}

The composition of the prey of each species of ant (one nest of each species) is given in Table 4 and can consist of specimens of up to 17 orders. Aphids make up a large part of the prey of all the species of ants studied, except that of $F$. pratensis, which did not include aphids. Prey

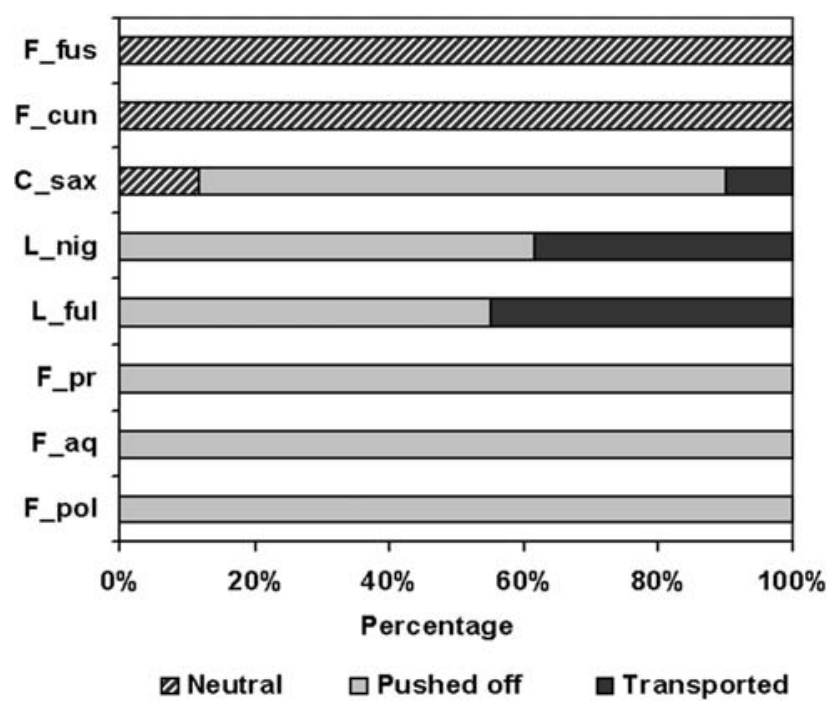

Fig. 3. Reactions of the various species of ants to "stranger" aphids in attended aphid colonies. The abbreviations are defined in Table 1. 
TABLE 4. The percentage composition of the prey of ants. The abbreviations are defined in Table 1.

\begin{tabular}{lcccccccc}
\hline \multicolumn{1}{c}{ Order/ ants } & F_pol & F_aq & F_pr & F_cun & F_fus & L_nig & L_ful & C_sax \\
\hline Hemiptera (aphids) & 33.9 & 20.6 & - & 41.2 & 10.6 & 33.7 & 30.3 & 10.5 \\
Hemiptera (other) & 11.9 & 5.9 & - & 8.7 & 10.6 & 5.6 & 9.0 & 14.3 \\
Coleoptera & 10.0 & 11.5 & 13.9 & 2.7 & 8.5 & 12.4 & 13.7 & - \\
Hymenoptera & 4.5 & 7.0 & 33.9 & 9.9 & 34.0 & 22.5 & 13.2 & 7.6 \\
Diptera & 4.5 & 7.0 & 4.6 & 7.7 & 4.3 & 21.3 & 10.7 & 6.7 \\
Heteroptera & 11.0 & 12.1 & 36.9 & 15.4 & 12.8 & 4.5 & 6.0 & 60.9 \\
Psocoptera & 0.3 & 3.1 & - & - & - & - & 0.9 & - \\
Lepidoptera & 3.9 & 6.8 & 4.6 & 0.6 & - & - & 1.3 & - \\
Neuroptera & 1.0 & 1.7 & 1.5 & 0.6 & 4.3 & - & - & - \\
Orthoptera & 0.6 & 1.4 & - & 1.1 & - & - & - & - \\
Diplura & 1.0 & 1.7 & - & - & - & - & - & - \\
Blattoptera & 0.6 & 1.1 & - & - & - & - & - & - \\
Thysanoptera & 1.6 & 2.3 & - & - & - & - & - & - \\
Raphidioptera & - & - & - & 0.6 & - & - & - & - \\
Mecoptera & - & - & - & 0.6 & - & - & - & - \\
Araneidae & 5.2 & 7.6 & 4.6 & 2.7 & 14.9 & - & 6.8 & - \\
Myriapoda & 1.3 & 2.0 & - & - & - & - & - & - \\
Gastropoda & 0.3 & 0.9 & - & - & - & - & - & - \\
Undetermined parts & 8.4 & 7.3 & - & 8.2 & - & - & 8.1 & - \\
\hline Total & 100 & 100 & 100 & 100 & 100 & 100 & 100 & 100 \\
\hline
\end{tabular}

includes both types of aphids: myrmecophilous and nonmyrmecophilous (Fig. 4), but is mainly made up of the latter. The number of species of myrmecophilous aphids taken as prey is significantly lower, with L. fuliginosus taking 5 and $F$. polyctena 3 species. It is worthy of note that there was 3 times more myrmecophilous than nonmyrmecophilous aphids living on grass and 30 times more on trees within the study areas. The aphids that were the main source of carbohydrate food for the ants studied were never attacked by ants. Observations on aphid colonies indicate that tending ants do not remove aphids. Moreover, red wood ants do not allow foraging ants to attack tended aphids: they actively attacked the foragers

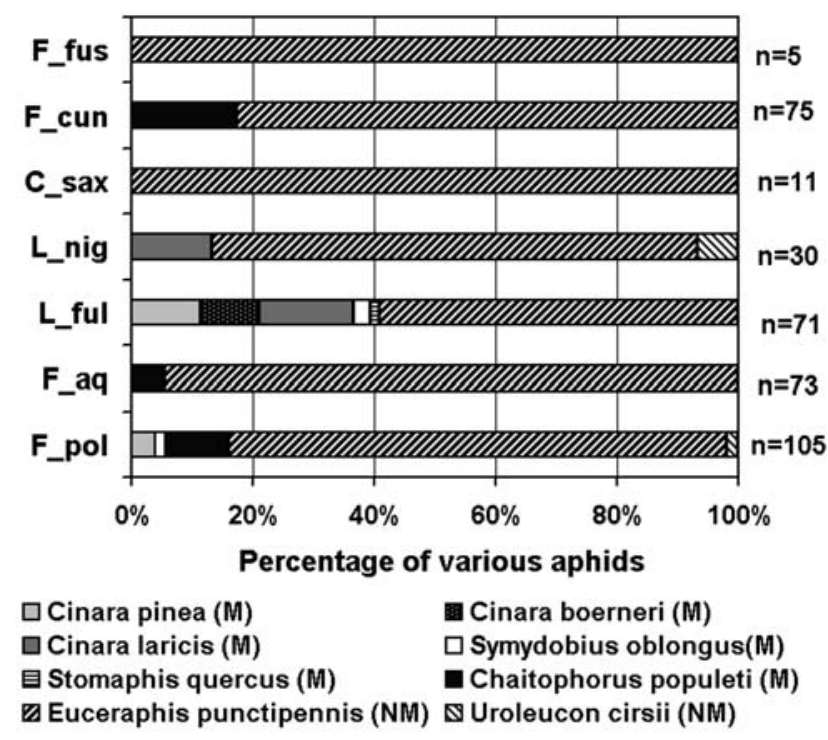

Fig. 4. The percentage of myrmecophilous (M) and nonmyrmecophilous (NM) aphids in the prey of the various species of ants. The abbreviations are defined in Table 1 .
(17 cases in $50 \mathrm{~h}$ of observation). Invalid or damaged aphids were transported to the nest only after a thorough examination (14-32 min; an average of 1194.17 \pm 321.89 s), when they stopped feeding and excreting honeydew. Only single individuals of Cinara pinea, Symydobius oblongus and Chaitophorus populeti were present in the food spectrum of $F$. polyctena.

The aphid prey of L. fuliginosus included both ant attended and non-attended species. Two aphid species on birch (Symydobius oblongus and Stomaphis quercus) were the main source of carbohydrate food for the colony of L. fuliginosus studied. No aphids were attacked by this ant during $100 \mathrm{~h}$ of observation. As in the case of the red wood ants only moribund aphids were transported to the nest. The high percentage (about 37\%) of the myrmecophilous species of aphids, Cinara pinea, C. boerneri and $C$. laricis, taken as prey by this ant may be due to a decrease in the attractiveness of these aphids. The honeydew of all three aphid species was actively collected by L. fuliginosus in spring and early summer (April-June 2002). However, later in the season the interest in these aphids decreased and their colonies became unattended. That is, ants only seem to kill unattended or damaged myrmecophilous aphids.

\section{DISCUSSION}

The close association between ants and aphids has attracted the interest of ecologists for over a century (Mordvilko, 1901, 1936; Sudd, 1987; Vepsäläinen \& Savolainen, 1994; Stadler et al., 2003). However, the behavioural interactions between these insects are poorly studied and a subject of debate. Some scientists assert that ants actively protect the aphids they tend (Addicott, 1978; Skinner \& Whittaker, 1981; Vepsäläinen \& Savolainen, 1994), while others think that they betray aphids to predators (Wellenstein, 1952; Bhatkar, 1983). Moreover, a few authors note that the benefits an aphid gains from tropho- 
biosis is very dependent on the species of ant (Bradley \& Hinks, 1968; Burns, 1973; Bristow, 1984). The benefits and costs of these relationships for aphids are closely connected with the behaviour of the ants.

This study revealed that the number of species of myrmecophilous aphids associated with species of ants differed. The greatest number was associated with the highly social red wood ants, which dominated the ant community studied. The mechanism underlying this phenomenon may be closely connected with the behaviour of the ants. The various species of ants showed different levels of interaction with aphids: professional specialization, partial division of labour and unspecialized workers (Novgorodova \& Reznikova, 1996; Novgorodova, 2002). Small groups of ants are typical of a partial division of labour, with usually 1-2 ants tending, guarding and collecting honeydew from aphids, and other ants transporting honeydew to the nest. The main differences between it and professional specialization, as in Formica s. str., is a clear division of the two functions: honeydew collecting and aphid colony protection. Both the red wood ants and F. pratensis have "shepherds", which solicit honeydew and "guards", which protect the aphids (Reznikova \& Novgorodova, 1998a, b, Novgorodova, 2002). In addition, the size of the group of ants tending an aphid colony is correlated with the number of tended aphids (Reznikova \& Novgorodova, 1996).

What are the advantages for aphids? It is well known that ladybirds eat aphids. Coccinella septempunctata, a good model of a potential predator, is readily attacked by Formica rufa (Sloggett et al., 1998). All the ants studied, except $F$. cunicularia and F. fusca, protect aphid colonies from this predator to some extent. Moreover, the ants that show professional specialization (Formica s. str.) do not switch from tending aphids to collecting protein food and never transport prey to the nest. Furthermore, only Formica s. str. takes care of aphids during bad weather (Reznikova \& Novgorodova, 1996; Novgorodova, 2002). These ants cover the aphids with their own bodies and protect them from being dislodged and killed, while aphid colonies tended by other ants suffer very heavy mortality from strong wind and heavy rain. Ants of these species are not active during heavy rain, at least in tending exposed colonies. They either return to their nest or hide under leaves or shelter nearby (Reznikova \& Novgorodova, 1996; Novgorodova, 2002). It is known that some ants, Lasius in particular, construct "shelters" over aphid colonies, which provide protection during bad weather (see review: Anderson \& McShea, 2001). Interestingly, studies on the relationship between L. fuliginosus and Stomaphis quercus have shown that the "builders" do not collect or transport honeydew (Novgorodova, 2002).

Whether ants are predators of aphids or not has interested many authors (Nixon, 1951; Way, 1963; Sakata, 1994) and is still a subject of discussion. A significant number of unattended aphids were found among the prey of F. rufa (Skinner, 1980). However, more interesting is whether myrmecophilous aphids are taken as prey by the ants that tend them (Skinner \& Whittaker, 1981; Cherix,
1987). We used a complex approach to explore this problem. An analysis of the kinds of prey collected by ants was accompanied by detailed observations on the behaviour of individually marked ants at aphid colonies. This provided answers to the following questions. What functional groups do the ants hunting for aphids belong to? Why do ants attack aphids?

It is known that the behaviour of ants towards their aphid partners can depend on the availability of alternative sources of food (Offenberg, 2001). In this study many unattended aphids were taken as prey by ants and single moribund specimens of myrmecophilous aphids were also removed from colonies. A decrease in the intensity of tending of aphid colonies lead to an increase in the proportion of these aphids taken as prey by ants. It seems to be connected with the recognition of "familiar" insects (symbionts). The species of ants that protect their territories recognize aphids that have been attended by the same colony. These aphids were never attacked by tending ants in contrast to individuals of the same species tended by other conspecific colonies of ants. Earlier it was shown that $F$. polyctena often reacted aggressively when an aphid left its colony. Ants recognize "familiar" aphids and try to return them to the colony (Reznikova \& Novgorodova, 1998a). Ants may mark attended aphids with a colony specific marker. It is not clear why ants abandon colonies of some aphid species. It may be connected with the amount of honeydew produced (Fischer et al., 2002). A detailed analysis of this question was beyond the scope of the present study. However, the intensity of ant-attendance did decline and was associated with an increase in the number of unmarked aphids taken as prey by the foragers. This accords with the data of Sakata (1994). He suggested that L. niger attacks and transports to its nest only unmarked aphids and that marking occurs during the course of honeydew collecting.

In summary, the degree of influence of ants on the growth and survival of aphid colonies seems to depend on the social and territorial organization of the ants and the complexity of the ant-aphid relationships. Red wood ants interacted with the most species of myrmecophilous aphids. Moreover, Formica s. str. shows the highest level of social and territorial organization, has the most complex behaviour and provides myrmecophilous aphids with the most services. So when Formica s. str. is present in multi-species ant communities it plays a dominant role in forming symbiotic relationships with aphids.

ACKNOWLEDGEMENTS. The study was supported by grants from the RFBR (05-04-48104), President of RF (NSH-1038.2003.4), "Russian Science Support Foundation" and Presidium of RAS (program "Origin and evolution of biosphere"). I would like to thank Zh.I. Reznikova for supervising this study, and S. Romanenko and A. Kruglova for their help in doing the experimental work. I thank both anonymous reviewers for their comments on a previous version of this manuscript, which greatly improved the presentation of the results.

\section{REFERENCES}

AddicotT J.F. 1978: Competition for mutualists: aphids and ants. Can. J. Zool. 56: 2093-2096. 
Anderson C. \& McShea D.W. 2001: Intermediary-level parts in insect societies: adaptive structures that ants build away from the nest. Ins. Soc. 48: 291-301.

BHATKAR A.P. 1983: Interspecific trophallaxis in ants, its ecological and evolutionary significance. In Jaisson P. (ed.): Social Insects in the Tropics 2. Université Paris-Nord, Paris, pp. 105-123.

Bradley G.A. \& HinKS J.D. 1968: Ants, aphids and jack pine in Manitoba. Can. Entomol. 100: 40-50.

BRISTOw C.M. 1984: Differential benefits from ant attendance to two species of Homoptera on New York ironweed. J. Anim. Ecol. 53: 715-726.

BuRns D.P. 1973: The foraging and tending behavior of Dolichoderus taschenbergi (Hymenoptera, Formicidae). Can. Entomol. 105: 97-104.

Cherix D. 1987: Relation between diet and polyethism in Formica colonies. Behav. Soc. Insects (Basel) 54: 93-115.

Cushman J.H. \& AdDicott J.F. 1991: Conditional interactions in ant-plant-herbivore mutualisms. In Huxley C.R. \& Culter D.F. (eds): Ant-Plant Interactions. Oxford University Press, New York, pp. 92-115.

Dlusskiy G.M. 1967: Ants of Genus Formica. Nauka, Moscow, 236 pp. (in Russian).

Dmitrienko V.K. \& Petrenko E.S. 1976: Ants of taiga biocenosis of Siberia. Nauka, Novosibirsk, 220 pp. (in Russian).

DobrZaŃsKa J. 1966: The control of the territory by Lasius fuliginosus Latr. Acta Biol. Exp. (Warsaw) 26(2): 193-213.

Fischer M.K., Völkl W., Schopf R. \& Hoffmann K.H. 2002: Age-specific patterns in honeydew production and honeydew composition in the aphid Metopeurum fuscoviride: implications for ant-attendance. Ins. Physiol. 48: 319-326.

Hölldobler B. \& Wilson E.O. 1990: The Ants. Springer, Berlin, $732 \mathrm{pp}$.

MordviLKo A.K. 1901: Biology and morphology of aphids. Proc. Russ. Entomol. Soc. 33: 418-475 (in Russian).

Mordvilko A.K. 1936: Ants and aphids. Priroda 4: 44-55 (in Russian).

Nixon G.E.J. 1951: The Association of Ants with Aphids and Coccids. Commonwealth Institute of Entomology. London, pp. $1-36$.

Novgorodova T.A. 2002: The Ethological Aspects of Ant-Aphid Interaction. PhD thesis. Novosibirsk, 23 pp. (in Russian).

Novgorodova T.A. 2004: The symbiotic relationships between ants and aphids. J. Gen. Biol. 65(2): 152-165 (in Russian, English abstr.).
Novgorodova T.A. \& Reznikova Zh.I. 1996: Ecological aspects of interaction between ants and aphids in the forest park zone of the Novosibirsk Scientific Center. Siber. J. Ecol. (3-4): 239-245.

Offenberg J. 2001: Balancing between mutualism and exploitation: the symbiotic interaction between Lasius ants and aphids. Behav. Ecol. Sociobiol. 49: 304-310.

Reznikova Zh.I. \& Novgorodova T.A. 1998a: The importance of individual and social experience for interaction between ants and symbiotic aphids. Dokl. Biol. Sci. 359: 173-175.

Reznikova Zh.I. \& Novgorodova T.A. 1998b: Division of labour and exchange of information within ant settlements. Usp. Sovrem. Biol. 118: 345-357 (in Russian, English abstr.).

Sakata H. 1994: How an ant decides to prey or to attend aphids. Rev. Popul. Ecol. 36(1): 45-51.

SkINNER G.J. 1980: The feeding habits of the wood-ants Formica rufa in a limestone woodland in Northwest England. J. Anim. Ecol. 49: 381-394.

SkinNeR G.J. \& WhitTaker J.B. 1981: An experimental investigation of interrelationships between the wood ant (Formica rufa) and some tree-canopy herbivores. J. Anim. Ecol. 50: 313-326.

Sloggett J.J., Wood R.A. \& Majerus M.E.N. 1998: Adaptations of Coccinella magnifica Redtenbacher, a myrmecophilous coccinellid, to aggression by wood ants (Formica rufa group). I. Adult behavioral adaptation, its ecological context and evolution. J. Ins. Behav. 11: 889-904.

Stadler B. \& Dixon A.F.G. 1999: Ant attendance in aphids: why different degrees of myrmecophily? Ecol. Entomol. 24: 363-369.

Stadler B., Kindlmann P., Šmilauer P. \& Fiedler K. 2003: A comparative analysis of morphological and ecological characters of European aphids and lycaenids in relation to ant attendance. Oecologia 135: 422-430.

SudD J.H. 1987: Ant aphid mutualism. In Minks A.K. \& Harrewijn P. (eds): Aphids. Their Biology, Natural Enemies and Control. (A). Elsevier, Amsterdam, pp. 355-365.

VepsäläINEN K. \& SAVOLAINEN R. 1994: Ant-aphid interaction and territorial dynamics of wood ants. Memor. Zool. 48: 251-259.

WAY M.J. 1963: Mutualism between ants and honeydew producing Homoptera. Annu. Rev. Entomol. 8: 307-344.

Wellenstein G. 1952: Zur Ernährungsbiologie der roten Waldameise (F. rufa L.) Z. Pflanzenkr. 59: 430-451.

Received September 30, 2004; revised and accepted February 24, 2005 